\title{
Metabolic versatility of the nitrite-oxidizing bacterium Nitrospira marina and its proteomic response to oxygen-limited conditions
}

\author{
Barbara Bayer $\mathbb{D}^{1} \cdot$ Mak A. Saito $\mathbb{1}^{2} \cdot$ Matthew R. Mcllvin ${ }^{2}$ - Sebastian Lücker $\mathbb{1}^{3}$ - Dawn M. Moran ${ }^{2}$. \\ Thomas S. Lankiewicz $\mathbb{B}^{1} \cdot$ Christopher L. Dupont $\mathbb{B}^{4} \cdot$ Alyson E. Santoro $\mathbb{B}^{1}$
}

Received: 2 July 2020 / Revised: 20 October 2020 / Accepted: 30 October 2020 / Published online: 23 November 2020

(c) The Author(s) 2020. This article is published with open access

\begin{abstract}
The genus Nitrospira is the most widespread group of nitrite-oxidizing bacteria and thrives in diverse natural and engineered ecosystems. Nitrospira marina $\mathrm{Nb}-295^{\mathrm{T}}$ was isolated from the ocean over 30 years ago; however, its genome has not yet been analyzed. Here, we investigated the metabolic potential of $N$. marina based on its complete genome sequence and performed physiological experiments to test genome-derived hypotheses. Our data confirm that $N$. marina benefits from additions of undefined organic carbon substrates, has adaptations to resist oxidative, osmotic, and UV light-induced stress and low dissolved $p \mathrm{CO}_{2}$, and requires exogenous vitamin $\mathrm{B}_{12}$. In addition, $N$. marina is able to grow chemoorganotrophically on formate, and is thus not an obligate chemolithoautotroph. We further investigated the proteomic response of $N$. marina to low $(\sim 5.6 \mu \mathrm{M}) \mathrm{O}_{2}$ concentrations. The abundance of a potentially more efficient $\mathrm{CO}_{2}$-fixing pyruvate:ferredoxin oxidoreductase (POR) complex and a high-affinity $c b b_{3}$-type terminal oxidase increased under $\mathrm{O}_{2}$ limitation, suggesting a role in sustaining nitrite oxidation-driven autotrophy. This putatively more $\mathrm{O}_{2}$-sensitive POR complex might be protected from oxidative damage by $\mathrm{Cu} / \mathrm{Zn}$-binding superoxide dismutase, which also increased in abundance under low $\mathrm{O}_{2}$ conditions. Furthermore, the upregulation of proteins involved in alternative energy metabolisms, including Group 3b [NiFe] hydrogenase and formate dehydrogenase, indicate a high metabolic versatility to survive conditions unfavorable for aerobic nitrite oxidation. In summary, the genome and proteome of the first marine Nitrospira isolate identifies adaptations to life in the oxic ocean and provides insights into the metabolic diversity and niche differentiation of NOB in marine environments.
\end{abstract}

Supplementary information The online version of this article (https:// doi.org/10.1038/s41396-020-00828-3) contains supplementary material, which is available to authorized users.

Barbara Bayer

bbayer@ucsb.edu

$\triangle$ Alyson E. Santoro

asantoro@ucsb.edu

1 Department of Ecology, Evolution and Marine Biology, University of California, Santa Barbara, CA, USA

2 Marine Chemistry and Geochemistry Department, Woods Hole Oceanographic Institution, Woods Hole, MA, USA

3 Department of Microbiology, IWWR, Radboud University, Nijmegen, The Netherlands

4 J. Craig Venter Institute, La Jolla, CA, USA

\section{Introduction}

Aerobic nitrite $\left(\mathrm{NO}_{2}^{-}\right)$oxidation is the main biochemical nitrate $\left(\mathrm{NO}_{3}{ }^{-}\right)$-forming reaction, carried out during the second step of nitrification [1]. In marine ecosystems, nitrate is the dominant form of biologically available nitrogen, which is rapidly assimilated by phytoplankton in surface waters and accumulates in the deep sea [2].

Nitrite-oxidizing bacteria (NOB) are chemolithoautotrophic microorganisms found within four known bacterial phyla (Proteobacteria, Nitrospirae, Nitrospinae, and Chloroflexi) [3]. The genus Nitrospira, within the Nitrospirae phylum, is the most diverse NOB genus and consists of at least six phylogenetic sublineages [3]. Nitrospira are ubiquitously present in natural and engineered ecosystems, including oceans [4, 5], freshwater habitats [6], soils [7, 8], saline-alkaline lakes [9], hot springs [10], wastewater treatment plants [11-13], and aquaculture biofilters [14, 15]. In human-made ecosystems, Nitrospira is generally 
considered to be adapted to low $\mathrm{NO}_{2}{ }^{-}$concentrations [16]. In the open ocean, however, where $\mathrm{NO}_{2}{ }^{-}$concentrations are exceedingly low, NOB affiliated with the phylum Nitrospinae appear to be the dominant nitrite oxidizers [4], whereas Nitrospira are found in relatively high $\mathrm{NO}_{2}{ }^{-}$environments including sediments and deep sea hydrothermal vent plumes $[17,18]$. Nitrospira also dominate over Nitrospinae-affiliated bacteria in some deep-sea trench environments $[19,20]$. High $\mathrm{NO}_{2}{ }^{-}$concentrations are found coincident with low $\mathrm{O}_{2}$ concentrations in oxygen minimum zone (OMZ) waters $[21,22]$ in a feature known as the secondary nitrite maximum with concentrations reaching $\sim 1-5 \mu \mathrm{M} \mathrm{NO}_{2}^{-}[23,24]$. Despite the $\mathrm{O}_{2}$-dependence of all known $\mathrm{NOB}, \mathrm{NO}_{2}{ }^{-}$ oxidation can still be detected at nanomolar $\mathrm{O}_{2}$ concentrations [25].

Some metabolic features appear to be common among Nitrospira, based on genomic analyses to date. Immunocytochemical analyses of a representative of Nitrospira sublineage I and metagenomic analyses of Nitrospira defluvii indicated a periplasmic orientation of nitrite oxidoreductase (NXR) [26, 27], the key enzyme for $\mathrm{NO}_{2}{ }^{-}$ oxidation, and the presence of the $\mathrm{O}_{2}$-sensitive reductive tricarboxylic acid (rTCA) cycle for inorganic carbon fixation [26]. These results suggest that Nitrospira evolved from microaerophilic or anaerobic ancestors [26]. $N$. defluvii lacks genes for classical oxidative stress defense enzymes present in most aerobic organisms including catalase and superoxide dismutase (SOD), indicative of adaptations to low $\mathrm{O}_{2}$ environmental niches [26]. However, other Nitrospira species encode both types of enzymes [28, 29], suggesting different $\mathrm{O}_{2}$ tolerances within members of the Nitrospira genus. In addition to $\mathrm{NO}_{2}{ }^{-}$oxidation, Nitrospira exhibit a high metabolic versatility, growing aerobically on hydrogen [30] or anaerobically on organic acids while respiring nitrate [28]. Recently, the capability for the complete oxidation of ammonia to nitrate (comammox) was identified in representatives of sublineage II Nitrospira [14, 31], however, comammox Nitrospira appear to be absent in marine systems [31].

Nitrospira marina $\mathrm{Nb}-295^{\mathrm{T}}$, the type species of the genus Nitrospira, was isolated from a water sample collected at a depth of $206 \mathrm{~m}$ from the Gulf of Maine in the Atlantic Ocean over 30 years ago [5]. It is the only Nitrospira species isolated from the oceanic water column and the environmental conditions favorable for Nitrospira in the ocean remain largely unexplored. Here, we investigated the metabolic potential of $N$. marina $\mathrm{Nb}-295^{\mathrm{T}}$ based on its complete genome sequence and compared the proteome signatures of cultures grown under atmospheric $\mathrm{O}_{2}$ tension and under low $\mathrm{O}_{2}$ conditions typically encountered in OMZs.

\section{Materials and methods}

\section{Cultivation of $\mathrm{N}$. marina $\mathrm{Nb}-295$}

A cryopreserved stock of $N$. marina $\mathrm{Nb}-295^{\mathrm{T}}$ was obtained from the culture collection of John B. Waterbury at the Woods Hole Oceanographic Institution. Strain Nb-295 was grown in $60 \mathrm{~mL}$ polycarbonate bottles (Nalgene) in $50 \mathrm{~mL}$ autotrophic mineral salts medium at $\mathrm{pH} 7.8$ containing $2 \mathrm{mM} \mathrm{NaNO}_{2}$ (Table S1), and bottles were incubated at $25^{\circ} \mathrm{C}$ in the dark without agitation. Mixotrophic growth was tested through the individual addition of the following organic carbon substrates to the culture medium of duplicate cultures (final concentrations): $150 \mathrm{mg} \mathrm{L}^{-1}$ yeast extract, $150 \mathrm{mg} \mathrm{L}^{-1}$ tryptone, $0.5 \mathrm{mM}$ pyruvate, or $1 \mathrm{~g} \mathrm{~L}^{-1}$ glycerol. $\mathrm{NO}_{2}^{-}$consumption was measured as previously described [32] and growth was monitored by flow cytometry (see Supplementary Methods). To test for chemoorganotrophic growth, the culture was transferred ( $2 \%$ inoculum) into $\mathrm{NO}_{2}{ }^{-}$-free medium containing either $1 \mathrm{mM}$ formate or $1 \mathrm{mM}$ pyruvate, and $100 \mu \mathrm{M}$ ammonium chloride, which served as nitrogen source.

For incubations at different $\mathrm{O}_{2}$ concentrations, triplicate cultures of $N$. marina $\mathrm{Nb}-295$ were grown at $22^{\circ} \mathrm{C}$ in $400 \mathrm{~mL}$ of medium containing $70 \%$ natural seawater and $2 \mathrm{mM}$ $\mathrm{NaNO}_{2}$ as described by Watson et al. [5] in $500 \mathrm{~mL}$ polycarbonate bottles (Nalgene) with a custom-made sparging rig. Bottles were constantly bubbled (flow rate: $15 \mathrm{~mL} \mathrm{~min}^{-1}$ ) with one of two sterile custom gas mixes containing either $0.5 \%$ or $20 \%$ oxygen, $300 \mathrm{ppm} \mathrm{CO}_{2}$, and a balance of highpurity $\mathrm{N}_{2} \cdot \mathrm{NO}_{2}{ }^{-}$concentrations were measured as a proxy for growth as described above and $10 \mathrm{~mL}$ aliquot of each culture was fixed at the last time point ( $2 \%$ formaldehyde, $\left.1 \mathrm{~h}, 4{ }^{\circ} \mathrm{C}\right)$ for cell enumeration on an epifluorescence microscope as previously described [33].

\section{DNA extraction, genome sequencing, and annotation}

High molecular weight genomic DNA was extracted from stationary phase cultures using a CTAB extraction protocol [34] and sequenced on the PacBio platform at the US Department of Energy Joint Genome Institute (JGI). 754,554 reads were produced, with 209,987 passing quality control. The assembly was conducted using HGAP (v 2.2.0.p1) with improvement with Quiver [35] resulting in a single contig.

Gene annotation was conducted using JGI's Integrated Microbial Genomes and Microbiomes pipeline [36] and the MicroScope platform [37]. Manual curation included sequence similarity searches using BLASTP (e-value $<1 \mathrm{e}^{-30}$ ) [38] against the Transporter Classification database [39] and protein domain searches using 
InterProScan (release 72.0) [40]. Signal peptides were identified with SignalP 5.0 [41] to determine if proteins were potentially addressed to the membrane and/or released to the periplasmic space. A list of manually curated annotations can be found in Data Set 1.

Phylogenomic analysis was performed using 120 concatenated phylogenetic marker genes from representatives of the phylum Nitrospirae/Nitrospirota as implemented in the Genome Taxonomy Database Toolkit (GTDB-tk) version 1.1.1 [42]. (see Supplementary Methods).

\section{Protein extraction and proteome analyses}

Cells for proteomic analysis were harvested when $\left[\mathrm{NO}_{2}{ }^{-}\right]$ dropped to $\sim 500 \mu \mathrm{M}$, corresponding to exponential growth of strain $\mathrm{Nb}-295$. Each culture was mixed with an equal volume of a house-made fixative [43] similar to the commercially available solution RNALater (Thermo Fisher), and filtered by vacuum filtration onto $25 \mathrm{~mm}, 0.2 \mu \mathrm{m}$ pore size Supor filters (Pall). $200 \mathrm{~mL}$ of fixed culture (equivalent to $100 \mathrm{~mL}$ of growth medium) were filtered for protein extraction and proteomic analyses. Filters were frozen at $-80^{\circ} \mathrm{C}$ until extraction. A detailed description of the procedures used for protein extraction and purification can be found in the Supplementary Methods. Global (untargeted) proteomes were analyzed on a Fusion Orbitrap mass spectrometer using one-dimensional nanospray separation and data-dependent acquisition based on Saito et al. [44] (see Supplementary Methods for detailed protocols). Select targeted quantitative proteomic assays using custom-made isotopically-labeled $\left({ }^{15} \mathrm{~N}\right)$ peptide standards were designed and samples were analyzed again by parallel reaction monitoring mass spectrometry using mass spectral information from the global proteome analyses as previously described [44] (also see Supplementary Methods). Tryptic peptides from ten proteins of interest, including nitrite oxidoreductase subunit alpha (NxrA), were targeted for absolute quantitation (see Data Set 2). Cellular NXR concentrations were calculated based on NxrA peptide concentrations using the average carbon content of N. marina cells (152 $\mathrm{fg}^{\text {cell }}{ }^{-1}$, Santoro et al., unpublished) and an estimated cellular protein:carbon ratio of $50 \%$ based on experimentally determined values [45]. NXR complex density on the cellular membrane was calculated using an estimated NXR complex size of $63 \mathrm{~nm}^{2}$ [27] and an estimated cell surface area of $2.45 \mu \mathrm{m}^{2}$ (assuming a cylindrical shape with a length of $1.75 \mu \mathrm{m}$ and a radius of $0.2 \mu \mathrm{m}$ based on previously determined cell dimensions of N. marina [5]).

Differential levels of expression between the two treatments (i.e., atmospheric $\mathrm{O}_{2}$ and low $\mathrm{O}_{2}$ conditions) were tested with the DESeq2 Bioconductor package (version 1.20.0) [46] in the $R$ software environment (version 3.5.0) [47] using spectral counts as input data as previously described [48]. Proteins with a mean spectral count below 6 across all treatments were excluded from the analysis. In DESeq2, only proteins that increased in abundance under low $\mathrm{O}_{2}$ conditions were considered ('altHyphothesis=greater'), $P$ values were adjusted using the Benjamini-Hochberg method ("pAdjustmethod $=\mathrm{BH}$ ") and independent filtering was omitted ("independentFiltering=FALSE"). Changes in protein abundance (as determined by spectral counts) were considered statistically significant when adjusted $P$ values were lower than or equal to 0.05 (see Data Set 3). While DESeq2 has a high precision and accuracy [49], it is more conservative than other methods on low-count transcripts/proteins [50]. Proteins of interest were visualized with the pheatmap package (version 1.0.12) [51] in the R software environment [47]. The normalized spectral abundance factor was calculated as proxy for relative protein abundances [52], and values were square-root transformed to improve visualization of low abundant proteins.

\section{Results and discussion}

\section{Genome analysis}

The genome of $N$. marina $\mathrm{Nb}-295$ is a single element of 4,683,627 bp and contains 4272 coding DNA sequences (CDS) including one rRNA operon. A $5578 \mathrm{bp}$ region of $99.7 \%$ identity on each end of the scaffold suggests circularization into a single chromosome. No plasmids or extrachromosomal elements were identified. The $\mathrm{G}+\mathrm{C}$ content is $50.04 \%$, lower than in other Nitrospira species and the marine nitrite-oxidizers Nitrospina gracilis and Nitrococcus mobilis (Table S2). Phylogenomic analysis of available closed genomes, metagenome-assembled genomes (MAGs) and single-cell amplified genomes affiliated with the phylum Nitrospirae (see Supplementary Methods) placed $N$. marina $\mathrm{Nb}-295^{\mathrm{T}}$ within a cluster of genomes derived from marine and saline environments (Fig. 1). The most closely related Nitrospira MAG (UBA8639) was obtained from a laboratory-scale nitrification reactor; however, the reactor influent consisted of 33\% untreated seawater [53], suggesting a marine origin of this MAG. The $16 \mathrm{~S}$ rRNA gene sequence of $N$. marina $\mathrm{Nb}-295^{\mathrm{T}}$ clustered together with environmental sequences derived from marine sediments and marine aquaculture biofilters (Fig. S1), and shared $99.1 \%$ and $97.9 \%$ sequence identity with the cultured lineage IV representatives Nitrospira sp. Ecomares 2.1 [15] and $\mathrm{Ca}$. Nitrospira alkalitolerans [9], respectively.

\section{Nitrogen metabolism and respiratory chain}

The genome of $N$. marina encodes orthologs of all known proteins required for $\mathrm{NO}_{2}{ }^{-}$oxidation, including the putatively periplasm-oriented NXR complex. Three candidates 

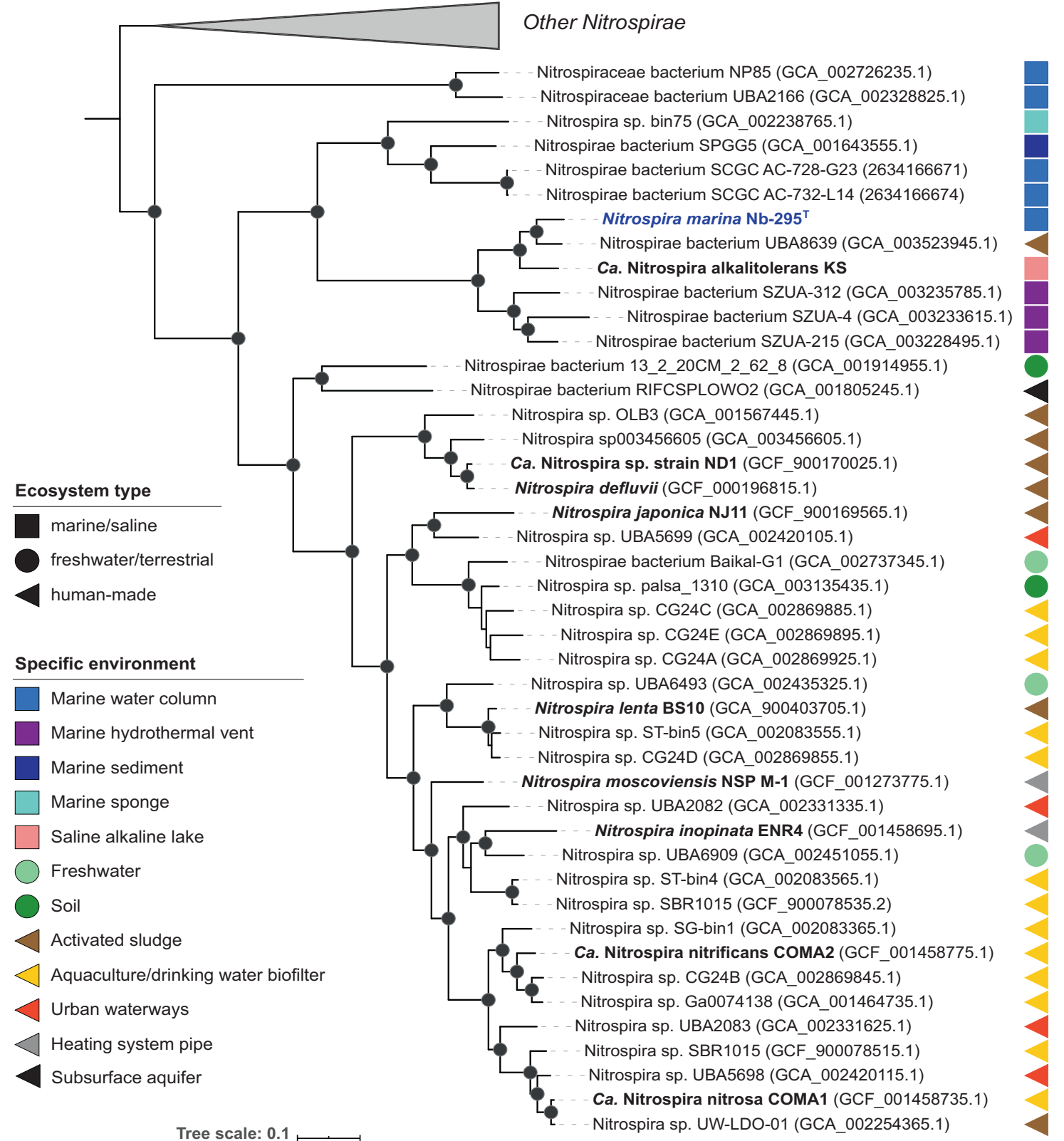

Fig. 1 Maximum likelihood phylogenetic tree of representatives of the phylum Nitrospirae. The multiple sequence alignment consisting of 120 concatenated phylogenetic marker genes contained 95 genomes and metagenome-assemble genomes (MAGs) from the Genome Taxonomy Database (GTDB) (Release 04-RS89, 19 June 2019), the genome of $N$. marina, the MAG of $C a$. N. alkalitolerans and two open

each of genes for $\mathrm{NxrA}, \mathrm{NxrB}$, and $\mathrm{NxrC}$, and two additional NxrC-like proteins were identified (Table S2, Data Set 1). The genes $n x r A$ and $n x r B$, encoding the alpha and beta subunits of NXR, are colocalized in three clusters, whereas all $n x r C$ candidate genes are localized separately from $n x r A B$, as previously described for Nitrospira moscoviensis [54]. The NxrA subunits share $87.3-88.9 \%$ amino acid identity, the NxrB subunits share $98.8-99.5 \%$ amino acid identity, and the putative $\mathrm{NxrC}$ subunits are less ocean single-cell amplified genomes (SAGs), AC-738-G23 and AC732-L14. All MAGs and SAGs were estimated to be $\geq 50 \%$ complete with $\leq 5 \%$ contamination. Nodes with UFBoot support of at least $95 \%$ are indicated as black filled circles. Cultured representatives are shown in bold. The scale bar represents 0.1 substitutions per site.

conserved, sharing between $33.7 \%$ and $86.9 \%$ amino acid identity.

Like all other analyzed Nitrospira genomes, N. marina encodes a putative copper-dependent NO-forming nitrite reductase (NirK), yet its function in Nitrospira and other NOB remains unknown. $N$. marina also encodes the ferredoxin-dependent nitrite reductase (NirA) for assimilatory nitrite reduction, which appears to be conserved in $\mathrm{Ca}$. Nitrospira lenta and N. defluvii but absent in other 
Nitrospira [55]. In addition, N. marina encodes three high affinity ammonium transporters (Amt) enabling direct uptake of reduced $\mathrm{N}$ for assimilation, and cyanate lyase to hydrolyze cyanate to ammonium and $\mathrm{CO}_{2}$ (Data Set 1). In contrast to some Nitrospira species [13, 28, 31], $N$. marina does not encode a urea transporter or urease, which would catabolize urea to ammonia for $\mathrm{N}$ assimilation (Table S2).

Previously sequenced genomes of Nitrospira contain multiple copies of several complexes of the respiratory chain [26, 28, 29, 54]. N. marina encodes two paralogous copies of complex I, one of which contains a duplication of NADH:quinone oxidoreductase subunit $\mathrm{M}$ (NuoM) and lacks genes for NuoE, NuoF and NuoH (Data Set 1), which is a characteristic feature of Nitrospira genomes [54, 56]. Furthermore, the $N$. marina genome contains two copies of complex III, two cytochrome $b d$ oxidases and seven putative cytochrome $b d$-like oxidases (Data Set 1), which show limited partial similarity to canonical cytochrome $b d$ oxidase subunit I as described for $N$. moscoviensis [54]. One of these cytochrome $b d$-like oxidases (bd-like_6) contains putative heme $\mathrm{b}$ and copper binding sites potentially functioning as a novel terminal oxidase as previously proposed [26]. N. marina also encodes for a $c b b_{3}$-type terminal oxidase, which usually exhibit high affinities for $\mathrm{O}_{2}$ [57]. This feature is shared with the closely related $\mathrm{Ca}$. N. alkalitolerans [9] and with the more distantly related marine NOB Nitrospina gracilis [58], but absent in all other Nitrospira species sequenced thus far. In addition to the canonical $\mathrm{H}^{+}$translocating $\mathrm{F}_{1} \mathrm{~F}_{0}$-ATPase (complex $\mathrm{V}$ ), N. marina also encodes a putative alternative $\mathrm{Na}^{+}$-translocating $\mathrm{N}$ ATPase (Data Set 1), which potentially contributes to the maintenance of the membrane potential and the generation of a sodium motive force (SMF) as suggested for $\mathrm{Ca}$. N. alkalitolerans [9]. Furthermore, a $\mathrm{H}^{+}$-translocating pyrophosphatase $\left(\mathrm{H}^{+}\right.$-PPase $)$with homology to Leptospiral protozoan/plant-type enzymes [59] was identified. $\mathrm{H}^{+}$-PPases couple the translocation of $\mathrm{H}^{+}$to the hydrolysis of the biosynthetic by-product pyrophosphate $\left(\mathrm{PP}_{\mathrm{i}}\right)$, which is suggested to be an adaptation to life under energy limitation [60]. The N. marina genome also contains an alternative complex III (ACIII) module, which shares similarity with that from sulfur-reducing Acidobacteria [61]. Like canonical complex III, ACIII also functions as a quinol oxidase transferring electrons to cytochrome $c$ and contributes to energy conservation (Refojo et al., 2012). With the exception of the comammox bacterium $\mathrm{Ca}$. Nitrospira nitrificans [14], no homologs of ACIII modules were identified in any other NOB genome.

$N$. marina encodes a putative $h y b$-like operon containing four subunits of a cytoplasmic Group 3b [NiFe] hydrogenase and six accessory proteins involved in hydrogenase assembly and maturation (Data Set 1). This type of hydrogenase appears to be conserved in the marine NOB Nitrospina gracilis 3/211 and Nitrococcus mobilis $\mathrm{Nb}-231$ [58, 62], Ca. N. alkalitolerans [9] and in comammox Nitrospira [14, 31] (Table S2). In addition to catalyzing the reversible, $\mathrm{NAD}^{+}$-dependent oxidation of hydrogen, these so-called sulfhydrogenases have been reported to reduce elemental sulfur $\left(\mathrm{S}^{\mathrm{o}}\right)$ or polysulfides to hydrogen sulfide $\left(\mathrm{H}_{2} \mathrm{~S}\right)$ [63]. Furthermore, the $N$. marina genome encodes a putative periplasmic sulfite:cytochrome $c$ oxidoreductase, which might couple sulfite $\left(\mathrm{SO}_{3}{ }^{2-}\right)$ oxidation to sulfate $\left(\mathrm{SO}_{4}{ }^{2-}\right)$ with the reduction of cytochrome $c$ as previously suggested for Nitrospina gracilis [58]. Contrastingly, sulfide/quinone oxidoreductase, which is speculated to mediate sulfide oxidation in Nitrococcus [62], is lacking. Whether or not these enzymes are involved in energy conservation using $\mathrm{H}_{2} \mathrm{~S}$ and $\mathrm{SO}_{3}{ }^{2-}$ as alternative substrates in NOB remains to be experimentally validated.

\section{Central carbon metabolism}

In agreement with other Nitrospira genomes [13, 26, 54, 55], $N$. marina encodes the complete gene repertoire for the rTCA cycle for carbon dioxide $\left(\mathrm{CO}_{2}\right)$ fixation, including the key enzymes ATP-citrate lyase and 2-oxoglutarate/pyruvate:ferredoxin oxidoreductase (Data Set 1). In the ocean, inorganic carbon is predominately available in the form of bicarbonate $\left(\mathrm{HCO}_{3}{ }^{-}\right)$and to a much lesser extent as $\mathrm{CO}_{2}$. Five inorganic anion transporters (SulP family) with homology to BicA $\mathrm{HCO}_{3}{ }^{-}$uptake systems of the cyanobacterium Synechococcus [64] were identified in the N. marina genome (Data Set 1). Two of these putative BicA-like transporters are colocalized with genes encoding $\mathrm{Na}^{+} / \mathrm{H}^{+}$antiporters (NhaB family), which could drive the uptake of $\mathrm{HCO}_{3}{ }^{-}$via $\mathrm{Na}^{+}$ extrusion under alkaline conditions as suggested for the cyanobacterium Aphanothece halophytica [65] and $\mathrm{Ca}$. N. alkalitolerans [9]. N. marina also encodes one putative SulPrelated bicarbonate transporter fused to a carbonic anhydrase and four genes encoding putative alpha, beta and gamma carbonic anhydrases (Data Set 1), which can convert the imported $\mathrm{HCO}_{3}{ }^{-}$to $\mathrm{CO}_{2}$ for inorganic carbon fixation via the rTCA cycle.

In addition to the rTCA cycle, $N$. marina encodes all required genes for the oxidative TCA cycle for pyruvate oxidation via acetyl-CoA, complete gluconeogenesis and glycolysis pathways, and the oxidative and non-oxidative branches of the pentose phosphate pathway (Data Set 1), which are common features of all sequenced Nitrospira genomes [9, 26, 28, 29, 55]. Furthermore, biosynthetic pathways for all amino acids except methionine were identified in the $N$. marina genome. Although $N$. marina encodes a vitamin $\mathrm{B}_{12}$-dependent methionine synthase (MetH) (Data Set 1), it appears to lack additional enzymes of known methionine biosynthesis pathways, a trait shared 
by all other sequenced Nitrospira species and Nitrospina gracilis $[9,26,28,29,55,58]$. However, as $N$. marina can grow in artificial seawater medium without added methionine, we hypothesize that an alternative unknown pathway for the early steps of methionine biosynthesis functions in Nitrospira and Nitrospina. The N. marina genome contains genes for the biosynthesis and degradation of the storage compounds glycogen and polyphosphate (Data Set 1). In contrast to other Nitrospira and the marine NOB $N$. gracilis and $N$. mobilis that encode a glgA-type glycogen synthase, $N$. marina encodes alpha-maltose-1phosphate synthase (glgM) and alpha-1,4-glucan:maltose-1phosphate maltosyltransferase (glgE) for the synthesis of glycogen via alpha-maltose-1-phosphate.

\section{Use of organic carbon substrates}

N. marina has been reported to be an obligate chemolithotroph that grows best in medium supplemented with low concentrations of organic compounds including pyruvate, glycerol, yeast extract and peptone [5]. Thus, we investigated the genomic basis for this observation and conducted additional physiological experiments.

In addition to its complete glycolysis pathway and oxidative TCA cycle, a putative carbohydrate degradation operon was identified, consisting of a sugar ABC transporter module, beta-glucosidase, a putatively secreted glycoside hydrolase (GH15) and a carbohydrate-binding protein (Data Set 1). N. marina also encodes two putative carbohydrate-selective porins (OprB), a sugar:sodium symporter (SSS family), a putative galactonate/glucarate transporter (MFS superfamily) and a putative carboxylate transporter (DASS family). The genomic repertoire for the catabolic degradation and assimilation of peptides and amino acids, including transporter proteins for di- and oligopeptides (ABC and POT/PTR families), multiple amino acid:cation symporters (SSS, DAACS and AGCS families), amino acid/polyamine transporters (APC superfamily) and multiple putatively secreted peptidases are present (Data Set 1).

In agreement with Watson et al. [5], $\mathrm{NO}_{2}{ }^{-}$oxidation activity was enhanced when undefined organic compound mixtures such as tryptone and yeast extract were added to the culture medium (Fig. 2). Interestingly, growth was greatly stimulated by tryptone (Fig. 2), while amendment with defined organic carbon compounds had no effect on $\mathrm{NO}_{2}{ }^{-}$oxidation or growth (Table S3). Parallel incubations with ammonium as an $\mathrm{N}$ source did not increase activity or growth (Table S3), suggesting that the stimulating effect of tryptone, and to a lesser extent of yeast extract, most likely can be attributed to direct amino acid assimilation and does not only reflect the eliminated energy demand for assimilatory $\mathrm{NO}_{2}{ }^{-}$reduction. No growth on yeast extract and

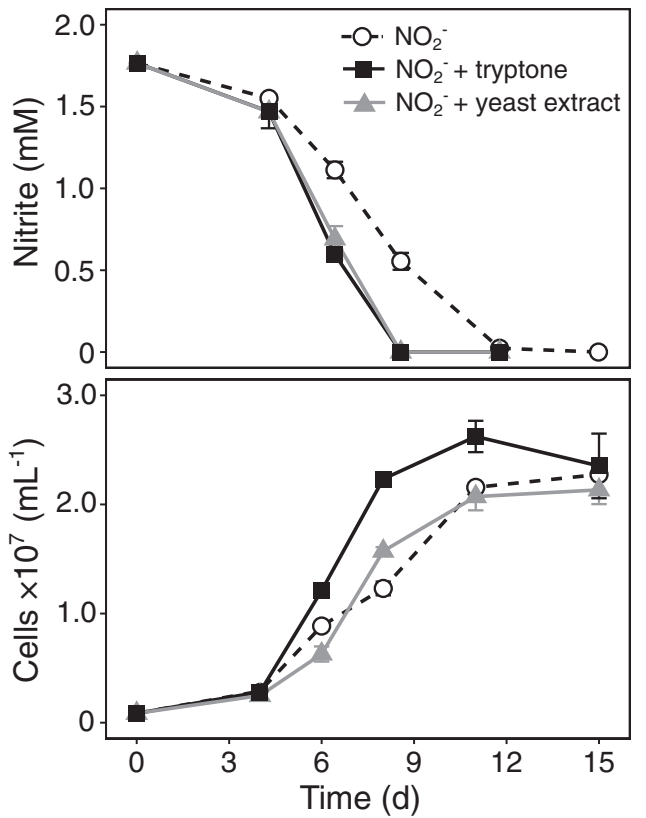

Fig. 2 The effect of undefined organic carbon substrates on nitrite oxidation and growth of $N$. marina $\mathbf{N b - 2 9 5}{ }^{\mathrm{T}}$. Error bars represent the range of measurements from duplicate cultures.

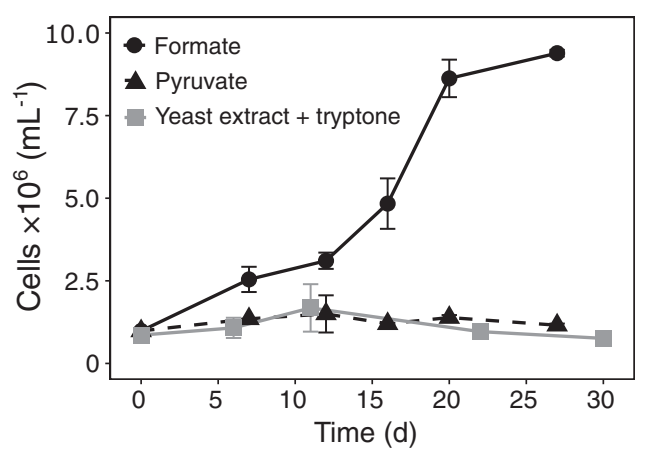

Fig. 3 Growth of $N$. marina $\mathrm{Nb}-295^{\mathrm{T}}$ on formate $(1 \mathrm{mM})$, pyruvate $(1 \mathrm{mM})$ and yeast extract and tryptone $\left(150 \mathrm{mg} \mathrm{L}^{-1}\right.$ each) in the absence of nitrite. Error bars represent the range of measurements from duplicate cultures.

tryptone was observed in the absence of $\mathrm{NO}_{2}{ }^{-}$(Fig. 3), corroborating their use as source of amino acids rather than for energy conservation.

In addition to undefined organic carbon substrates, defined organic compounds such as glycerol and pyruvate have been reported to enhance the growth of $N$. marina and $N$. defluvii, respectively [5, 12]. Formate has also been shown to serve as an electron donor and carbon source for some lineage I and II Nitrospira [11, 28]. N. marina encodes a putative formate dehydrogenase (FdhA) (Data Set 1 ), which is divergent from those found in $N$. moscoviensis and N. defluvii ( $\sim 24$ and $27 \%$ amino acid identity, respectively), but shares a relatively high sequence similarity 
( $\sim 48 \%$ amino acid identity) to the functionally characterized formate dehydrogenase Fdh4 from Methylobacterium extorquens [66]. N. marina was able to grow chemoorganotrophically on $1 \mathrm{mM}$ formate in the absence of $\mathrm{NO}_{2}{ }^{-}$ (Fig. 3) and is thus not an obligate chemolithotrophic organism. However, the use of formate instead of $\mathrm{NO}_{2}{ }^{-}$as electron donor resulted in slower growth rates, as previously also observed in $N$. moscoviensis [28]. In contrast to earlier reports [5], additions of $1 \mathrm{~g} \mathrm{~L}^{-1}$ glycerol did not stimulate $\mathrm{NO}_{2}{ }^{-}$oxidation activity or growth (Table S3). Furthermore, pyruvate could neither be used as alternative energy source (Fig. 3), nor did it stimulate metabolic activity in the presence of $\mathrm{NO}_{2}^{-}$(Table S3).

\section{Protection against oxidative, osmotic, and UV light-induced stress}

The formation of reactive oxygen species is prevalent in oxic environments and oxidative stress defense is an important component of the stress response in marine organisms [67]. $N$. marina encodes multiple enzymes to reduce oxidative stress, including a cytoplasmic $\mathrm{Mn} / \mathrm{Fe}$-binding SOD, a periplasmic $\mathrm{Cu} / \mathrm{Zn}$-binding SOD, two heme-containing catalases, and various peroxiredoxins (Data Set 1). In contrast, Nitrospina gracilis and marine ammonia-oxidizing archaea lack catalase $[48,58]$, suggesting that $N$. marina is less susceptible to oxidative stress compared to other marine nitrifiers. In addition to its plethora of oxidative stress defense-related proteins, $N$. marina also encodes two putative photolyases - enzymes known to be involved in the repair of UV light-induced DNA damage [68]—-suggesting that it is well adapted to conditions characteristic for euphotic environments.

Marine microorganisms counteract the external osmotic stress from high salt concentrations by accumulating a variety of organic solutes (=osmolytes) in the cytoplasm, which can either be synthesized de-novo or transported into the cell from the surrounding environment [69]. In addition to select amino acids that can serve as compatible solutes (e.g., proline and glutamate) [70], biosynthesis pathways for the osmolytes glycine betaine and trehalose were identified in the $N$. marina genome (see Supplementary Results and Discussion). The production and concomitant release of osmolytes (i.e., via diffusion, excretion, predation or cell lysis) could potentially fuel heterotrophic metabolism in the ocean [71] representing a link between chemolithoautotrophic production and heterotrophic consumption of DOM as recently suggested for ammonia-oxidizing archaea [72].

\section{Vitamin $B_{12}$ auxotrophy}

B vitamins are important biochemical co-factors required for cellular metabolism and their concentrations are depleted to near zero across large areas of the global ocean [73]. N. marina encodes complete biosynthetic pathways for the $\mathrm{B}$ vitamins thiamin $\left(\mathrm{B}_{1}\right)$, riboflavin $\left(\mathrm{B}_{2}\right)$, pantothenate $\left(\mathrm{B}_{5}\right)$, pyridoxine $\left(\mathrm{B}_{6}\right)$, biotin $\left(\mathrm{B}_{7}\right)$ and tetrahydrofolate $\left(\mathrm{B}_{9}\right)$. However, an incomplete vitamin $\mathrm{B}_{12}$ biosynthesis pathway was identified (Fig. S2), lacking genes for multiple precorrin conversion reactions that ultimately lead to the biosynthesis of the molecule's corrin ring [74]. Since $N$. marina only encodes the cobalamin-dependent versions of ribonucleotide reductase, methionine synthase and methylmalonyl-CoA mutase, it must rely on the supply of vitamin $B_{12}$ or its precursors by other members of the microbial community. Indeed, nitrite consumption by $N$. marina ceased after repeated transfers into an artificial seawater mineral medium without the addition of vitamin $\mathrm{B}_{12}$ (Fig. 4), and nitrite oxidation activity was restored after adding vitamin $B_{12}$ to $B_{12}$-deplete cultures (data not shown). Interestingly, the $N$. marina genome contains genes for multiple reactions that convert the precursor cobyrinate/ hydrogenobyrinate to cobalamin, and encodes all genes required for cobalamin salvage from cobinamide (Fig. S2, Data Set 1). Hence, in contrast to many other bacteria that lack the complete vitamin $\mathrm{B}_{12}$ biosynthesis pathway [75], $N$. marina appears to obtain its $\mathrm{B}_{12}$ from salvage of multiple intermediates from the environment. Vitamin $B_{12}$ auxotrophy has recently also been observed for several marine Nitrospinae strains [76]. In contrast, Park et al. [77] suggested that the two novel marine NOB strains MSP and DJ, one of which is closely related to $N$. marina, might be able to synthesize cobalamin. However, given that these cultures were not axenic and that genes involved in precorrin conversion reactions absent in N. marina (Fig. S2) are also missing from their genomes, it is likely that both strains depend on the exogenous supply of vitamin $\mathrm{B}_{12}$ as well.

When $N$. marina was grown in natural seawater, cellular concentrations of ribonucleotide reductase were approximately 39 -fold higher than for the cyanobacterium

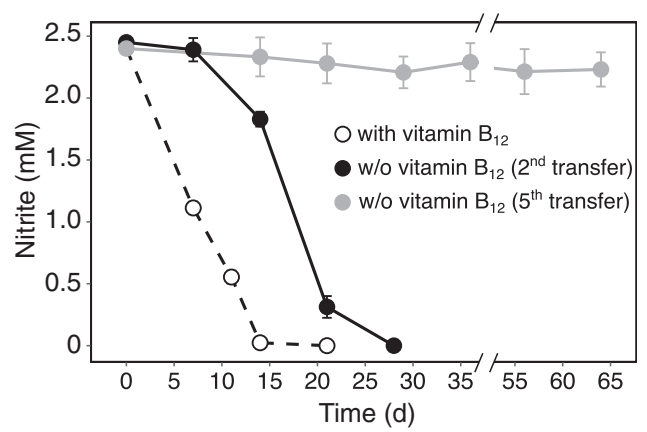

Fig. 4 Nitrite consumption by $N$. marina $\mathrm{Nb}^{-295}{ }^{\mathrm{T}}$ in artificial seawater mineral medium with and without addition of vitamin $\mathbf{B}_{12}$ (Table S1). Cultures of strain Nb-295 ${ }^{\mathrm{T}}$ were repeatedly transferred into medium without vitamin $\mathrm{B}_{12}$ using $2 \%$ inocula. Error bars represent the range of measurements from duplicate cultures. 
Table 1 Targeted quantitative analyses of selected proteins using isotopically-labeled $\left({ }^{15} \mathrm{~N}\right)$ peptide standards.

\begin{tabular}{llcr}
\hline Target protein $^{\mathrm{a}}$ & ${ }^{15}$ N-Peptide sequence & \multicolumn{2}{l}{$\begin{array}{l}\text { Peptide concentration } \\
\text { (copies cell }{ }^{-1} \text { ) }\end{array}$} \\
\cline { 4 - 4 } & & atm. $\mathrm{O}_{2}$ & low O $_{2}$ \\
\hline Nitrite oxidoreductase, alpha subunit 1 & LVVITPEYNPTAYR & $845(52)$ & $1924(275)$ \\
& DYAFPDFANSYSGK & $241(40)$ & $451(91)$ \\
& HPFWEETNESKPQWTR & $673(39)$ & $1571(388)$ \\
Nitrite oxidoreductase, alpha subunit 2 & VVVITPEYNPTAQR & $1,154(27)$ & $851(187)$ \\
Nitrite oxidoreductase, alpha subunit 3 & DYQFPDFTSTYSGK & $1,761(159)$ & $1,261(242)$ \\
& SGIDPALTGTHR & $4,519(516)$ & $3,400(526)$ \\
& IAVITPEYNPTAYR & $4,860(496)$ & $3,741(710)$ \\
Nitrite oxidoreductase, alpha subunit (all) & GWKPSDPYYK & $11,467(1,957)$ & $9,564(1,083)$ \\
& AIALDTGYQSNFR & $13,996(962)$ & $13,116(2,934)$ \\
Pyruvate:ferredoxin oxidoreductase, & TPSFFTGSEVIK & $2,026(192)$ & $1,550(248)$ \\
alpha subunit & EAIAILEEEGIR & $1,362(80)$ & $1,054(170)$ \\
& EVSATVPNNER & $2,453(169)$ & $1,736(215)$ \\
Ribonucleotide reductase & TGESPYQTIPFSHR & $300(46)$ & $198(30)$ \\
& EAAVPEPYIHR & $705(132)$ & $472(77)$ \\
& IINQSLPPALR & $750(88)$ & $546(68)$ \\
\hline
\end{tabular}

Nitrite oxidoreductase peptide targets were designed to match a specific NxrA copy (1, 2, or 3), or to match all three as indicated in the target protein column. Values represent the mean of triplicate measurements and standard deviations are shown in brackets.

${ }^{a} \mathrm{~A}$ complete list of quantified proteins can be found in Data Set 2.
Prochlorococcus [78] (Table 1) despite only having a two-fold greater cell volume, consistent with the importance of $\mathrm{B}_{12}$ nutrition to N. marina. Moreover, this salvage acquisition mode is interesting in the context of dissolved cobalt speciation, which is complexed by strong organic ligands hypothesized to include $\mathrm{B}_{12}$ precursors or degradation products [79]. In the Northwest Atlantic near where $N$. marina was isolated, organic cobalt complexes are abundant, comprising about half the dissolved cobalt inventory [80].

\section{Metabolic response to low oxygen concentrations}

Given the presence of multiple signatures of microaerophilic adaptation and metabolic diversity of nitrite oxidizers [26, 28, 58, 62] and their occurrence in low oxygen environments $[25,81,82]$, we sought to further investigate potential adaptations of Nitrospira marina $\mathrm{Nb}$ $295^{\mathrm{T}}$ to low $\mathrm{O}_{2}$ conditions. $N$. marina was grown at $\mathrm{O}_{2}$ concentrations characteristic for the upper ocean $(\sim 200 \mu \mathrm{M})$ and at $\mathrm{O}_{2}$-limiting conditions $\left(\sim 5.6 \mu \mathrm{M} \mathrm{O}_{2}\right)$ found in environments with elevated $\mathrm{NO}_{2}{ }^{-}$concentrations such as OMZ or sediments [83, 84].

When grown under atmospheric $\mathrm{O}_{2}$ concentration, $N$. marina oxidized $1.5 \mathrm{mM} \mathrm{NO}_{2}^{-}$within 12 days, whereas under $\mathrm{O}_{2}$-limiting conditions depletion of $1.5 \mathrm{mM}$ substrate took 27 days (Fig. 5). This result is in agreement with the initial description by Watson et al. [5], who reported partial,

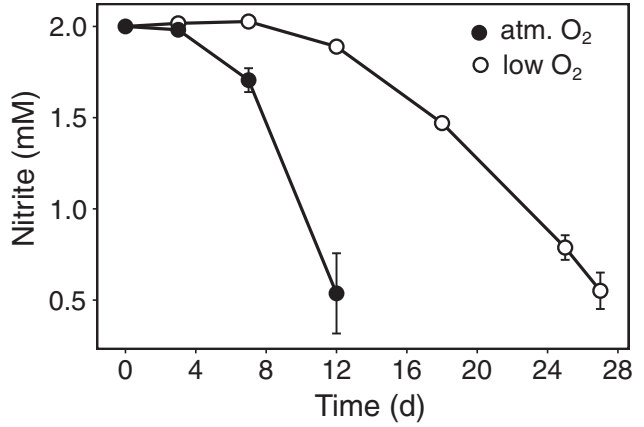

Fig. 5 Nitrite consumption by $N$. marina $\mathrm{Nb}-295^{\mathrm{T}}$ grown under atmospheric (filled circles) and low $\mathrm{O}_{2}$ conditions (open circles). Cells for proteome analysis were harvested after 12 and 27 days, respectively. Error bars represent standard deviations from measurements of triplicate cultures.

though unquantified, inhibition at low $\mathrm{O}_{2}$ partial pressure. Cell abundances at the final timepoint (after $1.5 \mathrm{mM} \mathrm{NO}_{2}{ }^{-}$ was oxidized) were comparable for both treatments (Fig. S3), indicating that the reduced $\mathrm{NO}_{2}^{-}$oxidation rate during $\mathrm{O}_{2}{ }^{-}$ limiting conditions ultimately resulted in similar cell yields.

\section{General proteomic response and upregulation of gene clusters}

Cultures grown under both $\mathrm{O}_{2}$ treatments were harvested for proteomic analysis when $\left[\mathrm{NO}_{2}^{-}\right]$dropped to $\sim 500 \mu \mathrm{M}$, 
corresponding to exponential growth of strain $\mathrm{Nb}-295$ (see "Material and Methods"). A total of 2031 and 2046 proteins were identified by liquid chromatography-tandem mass spectrometry in the atmospheric and low $\mathrm{O}_{2}$ treatments, respectively, accounting for 48.1 and $48.5 \%$ (49.7\% combined from a total of 175,653 peptides) of the predicted protein coding sequences in the $N$. marina genome. As previously reported for N. marina and Nitrococcus mobilis, proteins exhibiting the highest abundances were associated with $\mathrm{NO}_{2}{ }^{-}$oxidation [44] (Data Set 1). NXR made up on average $4 \%$ of all peptide spectral counts and cellular NXR concentrations were $\sim 13,500$ copies cell ${ }^{-1}$ as determined by targeted quantitative proteomic analyses (Table 1), covering an estimated $35 \%$ of the membrane surface (see "Material and Methods"). All three NxrA copies were detected in the proteome as determined by detection of unique peptides of each, and NxrA_3 appeared to be more abundant compared to NxrA_1 and NxrA_2 (Table 1). Under low $\mathrm{O}_{2}$ conditions, NxrA_1 increased in abundance (Table 1, Fig. 6) indicating different metabolic or regulatory roles of the highly similar subunits.

Proteins involved in $\mathrm{CO}_{2}$ fixation, DNA replication, electron transport and central carbon metabolism were also highly abundant under both conditions, indicating that $N$. marina retained its central metabolism during $\mathrm{O}_{2}$ deficiency (Data Set 1). Although proteomic spectral counts remained constant for the majority of proteins during both treatments, spectral counts of 93 proteins significantly increased (adjusted $P$ value $\leq 0.05$ ) during growth at low $\mathrm{O}_{2}$ concentrations (Fig. 6, Data Set 3). These results are supported by the targeted quantitative proteomic analyses (Fig. S4, Data Set 2), suggesting that spectral counts are a good proxy for changes in absolute protein abundance in our dataset.

Multiple universal stress proteins (UspA superfamily) were among the proteins that showed the highest increase in abundance under low $\mathrm{O}_{2}$ conditions compared to the control treatment (Fig. 6, Data Set 3). UspA proteins have versatile regulatory and protective functions to enable survival under diverse external stresses [85], and are induced during growth inhibition [86] and oxygen starvation [87]. In N. marina, all four upregulated UspA proteins are located upstream or downstream of operons containing genes that also increased in abundance under low $\mathrm{O}_{2}$ conditions (Fig. 6), suggesting a regulatory role of UspA-related proteins upon $\mathrm{O}_{2}$ limitation. These upregulated gene clusters include proteins involved in electron transport, carbon metabolism, and alternative energy metabolism (Fig. 6).

In addition to putative UspA-regulated gene clusters, a gene cluster containing type VI secretion system (T6SS)related proteins exhibited higher abundances under low $\mathrm{O}_{2}$ conditions (Fig. 6). The T6SS is typically involved in the secretion of effectors required for pathogenesis, bacterial competition, biofilm formation, and cell communication (e.g., quorum sensing) [88, 89]. While quorum sensing has recently been shown for diverse NOB including $N$. moscoviensis [90], no LuxI autoinducer synthases and/or LuxR signal receptor homologs were identified in the $N$. marina genome.

\section{Induction of a putative $\mathrm{O}_{2}$-sensitive 2-oxoacid:ferredoxin oxidoreductase complex}

The key enzymes of the rTCA cycle, pyruvate:ferredoxin oxidoreductase (POR) and 2-oxoglutarate:ferredoxin oxidoreductase (OGOR), are typically highly $\mathrm{O}_{2}$ sensitive because they contain easily oxidized iron-sulfur clusters [91]. In Hydrogenobacter thermophilus, five-subunit $\mathrm{O}_{2}$ tolerant forms of POR and OGOR mainly support aerobic growth, while a $\mathrm{O}_{2}$-sensitive two-subunit form is used under anaerobic conditions [92]. N. marina encodes three 2-oxoacid:ferredoxin oxidoreductase gene clusters that could exhibit POR or OGOR activity (Data Set 1). Two of these gene clusters consist of five CDS that exhibit a high sequence similarity to the $\mathrm{O}_{2}$-tolerant five-subunit POR/ OGOR of $H$. thermophilus [93, 94], as previously described for $N$. defluvii [26]. Both complexes were highly abundant in $N$. marina proteomes from atmospheric and low $\mathrm{O}_{2}$ treatments (Data Set 1, Table 1) confirming their important role in central carbon metabolism. The third cluster contains alpha, beta, and gamma subunits of a putative POR with homology to the functionally characterized four-subunit PORs of the anaerobic thermophiles Pyrococcus and Thermotoga [95] and is absent in all other Nitrospira with the exception of $\mathrm{Ca}$. N. alkalitolerans [9]. A protein with a 4Fe-4S binding domain was identified in the same operon, potentially representing the missing delta subunit of the POR complex (Data Set 1). This putative four-subunit POR was among the proteins that showed the highest increase in abundance under low $\mathrm{O}_{2}$ conditions in $N$. marina (Fig. 6). The $\mathrm{O}_{2}$-tolerant POR/OGOR isoforms were reported to have a >5-times lower specific activity [92] and might therefore constitute a substantial part of the cellular soluble protein content in $H$. thermophilus [96]. Hence, it is tempting to speculate that $N$. marina increases the expression of a more efficient (i.e., higher specific activity), $\mathrm{O}_{2}$-sensitive four-subunit POR under $\mathrm{O}_{2}$ limitation. While oxidative stress typically decreases under low $\mathrm{O}_{2}$ conditions, it might still be high enough to damage $\mathrm{O}_{2}$ sensitive enzymes. In $N$. marina, the abundance of a periplasmic $\mathrm{Cu} / \mathrm{Zn}$-binding SOD and a cytoplasmic catalase (KatG) increased under $\mathrm{O}_{2}$-limited conditions (Fig. 6), while the abundances of other oxidative stress defense-related proteins remained constant (Data Set 1 


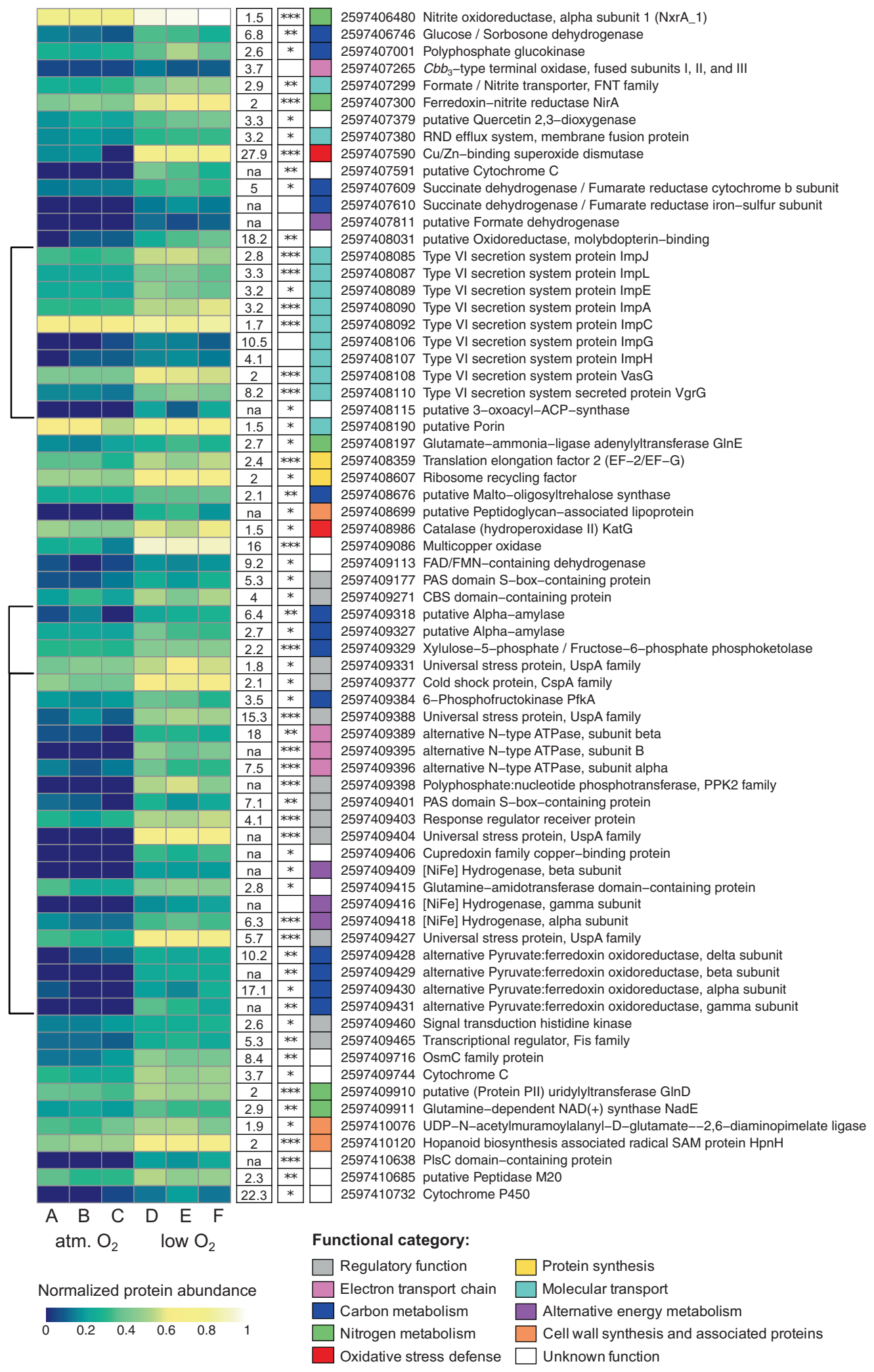

and 3). SOD has been shown to be efficient in protecting POR activity from oxidative damage in Entamoeba histolytica [97], and was among the proteins with the highest increase in abundance under low $\mathrm{O}_{2}$ conditions in $N$. marina (fold-change: 27.9), suggesting a role in POR protection. 
Fig. 6 Heat map of $N$. marina $\mathrm{Nb}-295^{\mathrm{T}}$ proteins that were more abundant under low $\mathrm{O}_{2}$ concentrations compared to atmospheric $\mathrm{O}_{2}$ concentration. Relative protein abundance values were squareroot transformed and hypothetical proteins were excluded to improve readability. The complete set of untransformed values can be found in Data Set 3. Fold-changes and significance values (adj. $P$ value $\leq 0.001$, $* * * ; \leq 0.01, * * ; \leq 0.05, *)$ are shown in white boxes next to the corresponding protein. Select low abundant proteins of interest with high fold-changes were included despite being not statistically significant (see "Material and Methods"). Fold-changes of proteins that were not detected under atmospheric $\mathrm{O}_{2}$ conditions are omitted to avoid dividing by zero (not available, na). Functional categories of depicted proteins are indicated by different colors. Gene clusters are indicated by black brackets.

\section{Expression of a high $\mathrm{O}_{2}$-affinity $c b b_{3}$-type terminal oxidase}

The majority of proteins related to electron transport showed similar abundance levels at atmospheric and limiting $\mathrm{O}_{2}$ concentrations (Data Set 1 and 3). Despite its overall low abundance, a putative high-affinity cytochrome $c b b_{3^{-}}$ type terminal oxidase was 3.6-times more abundant under low $\mathrm{O}_{2}$ concentrations compared to atmospheric $\mathrm{O}_{2}$ tension (Fig. 6). The $c b b_{3}$-type terminal oxidase of Bradyrhizobium japonicum was reported to have a $K_{\mathrm{m}}$ value of $7 \mathrm{nmol} \mathrm{L}^{-1}$ $\mathrm{O}_{2}$ [98] and $\mathrm{NO}_{2}{ }^{-}$oxidation rates have been detected at $\mathrm{O}_{2}$ concentrations in the low nanomolar range $\left(5-33 \mathrm{nmol} \mathrm{L}^{-1}\right.$ $\mathrm{O}_{2}$ ) [25]. This suggests that the $c b b_{3}$-type terminal oxidase might enable $N$. marina to continue aerobic respiration at low $\mathrm{O}_{2}$ concentrations, albeit at lower $\mathrm{NO}_{2}{ }^{-}$oxidation rates (Fig. 5). Low-affinity terminal oxidases are typically more efficient in energy conservation [99], suggesting that $N$. marina benefits from the presence of a terminal oxidase with lower $\mathrm{O}_{2}$ affinity in well-oxygenated environments. While $N$. gracilis encodes a highly similar high affinity $c b b_{3}$-type terminal oxidase to $N$. marina [58], this enzyme is lacking in other Nitrospinae, including those identified in OMZs and sediments [76, 82, 100]. Interestingly, these genomes also lack the putative terminal oxidase proposed for Nitrospira [26]. Still, in an OMZ where Nitrospinae bacteria were the only detected $\mathrm{NOB}, \mathrm{NO}_{2}{ }^{-}$oxidation rates already approached saturation at $\sim 1 \mu \mathrm{mol} \mathrm{\textrm {L } ^ { - 1 }} \mathrm{O}_{2}$ [25], indicating that Nitrospinae bacteria might be better adapted to low $\mathrm{O}_{2}$ concentrations compared to $N$. marina, but the enzyme conferring high $\mathrm{O}_{2}$ affinity in Nitrospinae remains to be identified.

\section{Increase in abundance of proteins involved in alternative energy metabolism}

The abundance of proteins putatively involved in alternative energy metabolisms increased under low $\mathrm{O}_{2}$ concentrations. These included Group 3b [NiFe] hydrogenase and formate dehydrogenase (Fig. 6). Alternative electron donors such as $\mathrm{H}_{2}$ and formate are common reaction products at oxic/anoxic interfaces [101]. N. moscoviensis can couple $\mathrm{H}_{2}$ and formate oxidation to $\mathrm{NO}_{3}{ }^{-}$reduction to remain active under anoxia [28, 30] (whereas no net growth was observed for the former [30]), however, it is unlikely that $\mathrm{H}_{2}$ or formate were present at the culture conditions in this study. While abundances of hydrogenase and formate dehydrogenase increased under low $\mathrm{O}_{2}$ conditions, they were overall still comparably low (Fig. 6), suggesting that their expression might be upregulated when conditions become more unfavorable for aerobic $\mathrm{NO}_{2}^{-}$oxidation. Curiously, multiple subunits of the $\mathrm{Na}^{+}$-translocating $\mathrm{N}$-type ATPase exhibited higher abundances at low $\mathrm{O}_{2}$ concentration (Fig. 6). $\mathrm{Na}^{+}$-translocating ATPases are suggested to be ancient enzymes that were later replaced by energetically more favorable $\mathrm{H}^{+}$-translocating ATPases [102]. While only few obligate anaerobes with very tight energy budgets (which cannot cover the losses caused by proton leaks) primarily use $\mathrm{Na}^{+}$energetics, many organisms retained $\mathrm{Na}^{+}$pumps and utilize them under energetically less favorable conditions such as anaerobiosis [102]. Hence, expression of a $\mathrm{Na}^{+}$-translocating ATPase suggests an adaptation of $N$. marina to overcome periods of starvation when energetically favorable electron donors or acceptors are short in supply.

\section{Conclusions}

Although the vast majority of the ocean is well oxygenated, oxygen-depleted zones exist within the oceanic water column and in marine sediments [83, 84] with consequences for microbial adaptation and evolution. Our results show that, in contrast to Nitrospinae-dominated NOB populations in low oxygen waters [25], $\mathrm{NO}_{2}{ }^{-}$oxidation activity of Nitrospira marina was reduced when grown at $\sim 5.6 \mu \mathrm{M} \mathrm{O}_{2}$, suggesting different $\mathrm{O}_{2}$ adaptations among different marine NOB. We confirm that $N$. marina benefits from the addition of undefined organic carbon substrates, which were shown to be inhibitory for Nitrospina gracilis [103], potentially further contributing to ecological niche partitioning within marine NOB. Our results indicate that $N$. marina is highly metabolically versatile, which might enable it to survive under unfavorable conditions with fluctuating levels of electron donors and acceptors. Hence, while Nitrospinae bacteria are the dominant nitrite oxidizers in oligotrophic oceanic regions and OMZs, Nitrospira might be better adapted to well-oxygenated high productivity regions including coastal systems, deep-sea trenches and hydrothermal vents. Finally, our results also indicate several ways that NOB may interact with other members of the marine microbial community-through the supply of organic carbon-containing osmolytes and their requirement for exogenous vitamin $\mathrm{B}_{12}$. 


\section{Data availability}

The genome of Nitrospira marina $\mathrm{Nb}-295^{\mathrm{T}}$ is available in the JGI IMG/M repository under genome ID number 2596583682. Manually curated protein annotations are available in Data Set 1, targeted quantitative proteomic analyses results are available in Data Set 2, global proteomic spectral counts and differential expression analysis results are available in Data Set 3. Raw mass spectra are available in PRIDE as project number PXD021606. Data is archived at Biological and Chemical Oceanography Data Management office (BCO-DMO) under project 806565.

Acknowledgements We thank John B. Waterbury and Frederica Valois for providing the culture of Nitrospira marina $\mathrm{Nb}-295^{\mathrm{T}}$ and for continued advice about cultivation. The $N$. marina genome was sequenced as part of US Department of Energy Joint Genome Institute Community Sequencing Project 1337 to CLD, AES, and MAS in collaboration with the user community. We thank Claus Pelikan for bioinformatic assistance. This research was supported by a Simons Foundation Early Career Investigator in Marine Microbiology and Evolution Award (345889) and US National Science Foundation (NSF) award OCE-1924512 to AES. Proteomics analysis was supported by NSF awards OCE-1924554 and OCE-1850719, and NIH award R01GM135709 to MAS. BB was supported by the Austrian Science Fund (FWF) Project Number: J4426-B ("The influence of nitrifiers on the oceanic carbon cycle"), SL by the Netherlands Organization for Scientific Research (NWO) grant 016.Vidi.189.050, and CLD by NSF award OCE-125999.

\section{Compliance with ethical standards}

Conflict of interest The authors declare that they have no conflict of interest.

Publisher's note Springer Nature remains neutral with regard to jurisdictional claims in published maps and institutional affiliations.

Open Access This article is licensed under a Creative Commons Attribution 4.0 International License, which permits use, sharing, adaptation, distribution and reproduction in any medium or format, as long as you give appropriate credit to the original author(s) and the source, provide a link to the Creative Commons license, and indicate if changes were made. The images or other third party material in this article are included in the article's Creative Commons license, unless indicated otherwise in a credit line to the material. If material is not included in the article's Creative Commons license and your intended use is not permitted by statutory regulation or exceeds the permitted use, you will need to obtain permission directly from the copyright holder. To view a copy of this license, visit http://creativecommons. org/licenses/by/4.0/.

\section{References}

1. Kuypers MMM, Marchant HK, Kartal B. The microbial nitrogen-cycling network. Nat Rev Microbiol. 2018; 16:263-76.

2. Gruber N. The marine nitrogen cycle: Overview and challenges. In: G Capone, DA Bronk, MR Mulholland, EJ Carpenter (eds).
Nitrogen in the marine environment, 2nd ed. Academic Press: New York, NY, 2008, pp. 1-50.

3. Daims H, Lücker S, Wagner M. A new perspective on microbes formerly known as nitrite-oxidizing bacteria. Trends Microbiol. 2016;24:699-712.

4. Pachiadaki MG, Sintes E, Bergauer K, Brown JM, Record NR, Swan BK, et al. Major role of nitrite-oxidizing bacteria in dark ocean carbon fixation. Science. 2017;358:1046-51.

5. Watson SW, Bock E, Valois FW, Waterbury JB, Schlosser U. Nitrospira marina gen. nov. sp. nov.: a chemolithotrophic nitriteoxidizing bacterium. Arch Microbiol. 1986;144:1-7.

6. Altmann D, Stief P, Amann R, De Beer D, Schramm A. In situ distribution and activity of nitrifying bacteria in freshwater sediment. Environ Microbiol. 2003;5:798-803.

7. Freitag TE, Chang L, Clegg CD, Prosser JI. Influence of inorganic nitrogen management regime on the diversity of nitriteoxidizing bacteria in agricultural grassland soils. Appl Environ Microbiol. 2005;71:8323-34.

8. Pester M, Maixner F, Berry D, Rattei T, Koch H, Lücker S, et al. $N x r B$ encoding the beta subunit of nitrite oxidoreductase as functional and phylogenetic marker for nitrite-oxidizing Nitrospira. Environ Microbiol. 2014;16:3055-71.

9. Daebeler A, Kitzinger K, Koch H, Herbold CW, Steinfeder M, Schwarz J, et al. Exploring the upper $\mathrm{pH}$ limits of nitrite oxidation: diversity, ecophysiology, and adaptive traits of haloalkalitolerant Nitrospira. ISME J. 2020. https://doi.org/10.1038/s41396-0200724-1.

10. Lebedeva EV, Alawi M, Fiencke C, Namsaraev B, Bock E, Spieck E. Moderately thermophilic nitrifying bacteria from a hot spring of the Baikal rift zone. FEMS Microbiol Ecol. 2005;54: 297-306.

11. Gruber-Dorninger C, Pester M, Kitzinger K, Savio DF, Loy A, Rattei T, et al. Functionally relevant diversity of closely related Nitrospira in activated sludge. ISME J. 2015;9:643-55.

12. Spieck E, Hartwig C, McCormack I, Maixner F, Wagner M, Lipski A, et al. Selective enrichment and molecular characterization of a previously uncultured Nitrospira-like bacterium from activated sludge. Environ Microbiol. 2006;8:405-15.

13. Ushiki N, Fujitani H, Aoi Y, Tsuneda S. Isolation of Nitrospira belonging to sublineage II from a wastewater treatment plant. Microbes Environ. 2013;28:346-53.

14. Van Kessel MAHJ, Speth DR, Albertsen M, Nielsen PH, Op Den Camp HJM, Kartal B, et al. Complete nitrification by a single microorganism. Nature. 2015;528:555-9.

15. Keuter S, Kruse M, Lipski A, Spieck E. Relevance of Nitrospira for nitrite oxidation in a marine recirculation aquaculture system and physiological features of a Nitrospira marina-like isolate. Environ Microbiol. 2011;13:2536-47.

16. Nowka B, Off S, Daims H, Spieck E. Improved isolation strategies allowed the phenotypic differentiation of two Nitrospira strains from widespread phylogenetic lineages. FEMS Microbiol Ecol. 2015;91:fiu031.

17. Hongxiang X, Min W, Xiaogu W, Junyi Y, Chunsheng W. Bacterial diversity in deep-sea sediment from northeastern Pacific Ocean. Acta Ecol Sin. 2008;28:479-85.

18. Baker BJ, Sheik CS, Taylor CA, Jain S, Bhasi A, Cavalcoli JD, et al. Community transcriptomic assembly reveals microbes that contribute to deep-sea carbon and nitrogen cycling. ISME J. 2013;7:1962-73.

19. Nunoura T, Takaki Y, Hirai M, Shimamura S, Makabe A, Koide $\mathrm{O}$, et al. Hadal biosphere: Insight into the microbial ecosystem in the deepest ocean on Earth. Proc Natl Acad Sci USA. 2015;112:E1230-6.

20. Hiraoka S, Hirai M, Matsui Y, Makabe A, Minegishi H, Tsuda M, et al. Microbial community and geochemical analyses 
of trans-trench sediments for understanding the roles of hadal environments. ISME J. 2020;14:740-56.

21. Lam P, Kuypers MMM. Microbial nitrogen cycling processes in oxygen minimum zones. Ann Rev Mar Sci. 2011; 3:317-45.

22. Codispoti LA, Friederich GE, Packard TT, Glover HE, Kelly PJ, Spinrad RW, et al. High nitrite levels off northern Peru: a signal of instability in the marine denitrification rate. Science. 1986;233:1200-2.

23. Buchwald C, Santoro AE, Stanley RHR, Casciotti KL. Nitrogen cycling in the secondary nitrite maximum of the eastern tropical North Pacific off Costa Rica. Glob Biogeochem Cycles. 2015;29: 2061-81.

24. Lam P, Jensen MM, Kock A, Lettmann KA, Plancherel Y, Lavik $\mathrm{G}$, et al. Origin and fate of the secondary nitrite maximum in the Arabian Sea. Biogeosciences. 2011;8:1565-77.

25. Bristow LA, Dalsgaard T, Tiano L, Mills DB, Bertagnolli AD, Wright JJ, et al. Ammonium and nitrite oxidation at nanomolar oxygen concentrations in oxygen minimum zone waters. Proc Natl Acad Sci USA. 2016;113:10601-6.

26. Lücker S, Wagner M, Maixner F, Pelletier E, Koch H, Vacherie B, et al. A Nitrospira metagenome illuminates the physiology and evolution of globally important nitrite-oxidizing bacteria. Proc Natl Acad Sci USA. 2010;107:13479-84.

27. Spieck E, Ehrich S, Aamand J, Bock E. Isolation and immunocytochemical location of the nitrite-oxidizing system in Nitrospira moscoviensis. Arch Microbiol. 1998;169:225-30.

28. Koch H, Lücker S, Albertsen M, Kitzinger K, Herbold C, Spieck E, et al. Expanded metabolic versatility of ubiquitous nitriteoxidizing bacteria from the genus Nitrospira. Proc Natl Acad Sci USA. 2015;112:11371-6.

29. Ushiki N, Fujitani H, Shimada Y, Morohoshi T, Sekiguchi Y, Tsuneda S. Genomic analysis of two phylogenetically distinct Nitrospira species reveals their genomic plasticity and functional diversity. Front Microbiol. 2018;8:2637.

30. Koch H, Galushko A, Albertsen M, Schintlmeister A, GruberDorninger C, Lücker S, et al. Growth of nitrite-oxidizing bacteria by aerobic hydrogen oxidation. Science. 2014;345: 1052-4.

31. Daims H, Lebedeva EV, Pjevac P, Han P, Herbold C, Albertsen $\mathrm{M}$, et al. Complete nitrification by Nitrospira bacteria. Nature. 2015;528:504-9.

32. Strickland JDH, Parsons TR A practical handbook of seawater analysis, 2nd ed. 1972. Fish. Res. Bd. Can., Bull. No. 167

33. Porter KG, Feig YS. The use of DAPI for identifying aquatic microflora. Limnol Oceanogr. 1980;25:943-8.

34. Wilson K. Preparation of genomic DNA from bacteria. Curr Protoc Mol Biol. 2001;56:2.4.1-5.

35. Chin CS, Alexander DH, Marks P, Klammer AA, Drake J, Heiner $\mathrm{C}$, et al. Nonhybrid, finished microbial genome assemblies from long-read SMRT sequencing data. Nat Methods. 2013;10:563-9.

36. Markowitz VM, Chen I-MA, Palaniappan K, Chu K, Szeto E, Grechkin Y, et al. IMG: the Integrated Microbial Genomes database and comparative analysis system. Nucleic Acids Res. 2012;40:D115-22.

37. Vallenet D, Calteau A, Dubois M, Amours P, Bazin A, Beuvin $\mathrm{M}$, et al. MicroScope: an integrated platform for the annotation and exploration of microbial gene functions through genomic, pangenomic and metabolic comparative analysis. Nucleic Acids Res. 2020;48:D579-89.

38. Altschul SF, Gish W, Miller W, Myers EW, Lipman DJ. Basic local alignment search tool. J Mol Biol. 1990;215:403-10.

39. Saier MH. TCDB: the transporter classification database for membrane transport protein analyses and information. Nucleic Acids Res. 2006;34:D181-6.
40. Quevillon E, Silventoinen V, Pillai S, Harte N, Mulder N, Apweiler R, et al. InterProScan: protein domains identifier. Nucleic Acids Res. 2005;33:W116-20.

41. Almagro Armenteros JJ, Tsirigos KD, Sønderby CK, Petersen TN, Winther O, Brunak S, et al. SignalP 5.0 improves signal peptide predictions using deep neural networks. Nat Biotechnol 2019. https://doi.org/10.1038/s41587-019-0036-z.

42. Chaumeil P-A, Mussig AJ, Hugenholtz P, Parks DH. GTDB-Tk: a toolkit to classify genomes with the Genome Taxonomy Database. Bioinformatics. 2019;36:1925-7.

43. Malmstrom R RNAlater Recipe. protocols.io 2015. https://doi. org/10.17504/protocols.io.c56y9d.

44. Saito MA, Mcilvin MR, Moran DM, Santoro AE, Dupont CL, Rafter PA, et al. Abundant nitrite-oxidizing metalloenzymes in the mesopelagic zone of the tropical Pacific Ocean. Nat Geosci. 2020;13:355-62.

45. Simon M, Azam F. Protein content and protein synthesis rates of planktonic marine bacteria. Mar Ecol Prog Ser. 1989;51:201-13.

46. Love MI, Huber W, Anders S. Moderated estimation of fold change and dispersion for RNA-seq data with DESeq2. Genome Biol. 2014;15:550.

47. R Core Team. R: A language and environment for statistical computing. R Foundation for Statistical Computing, Vienna, Austria. 2013. http://www.R-project.org.

48. Bayer B, Pelikan C, Bittner MJ, Reinthaler T, Könneke M, Herndl GJ, et al. Proteomic response of three marine ammonia-oxidizing archaea to hydrogen peroxide and their metabolic interactions with a heterotrophic alphaproteobacterium. mSystems. 2019;4: e00181-19.

49. Langley SR, Mayr M. Comparative analysis of statistical methods used for detecting differential expression in label-free mass spectrometry proteomics. J Proteom. 2015;129:83-92.

50. Raithel S, Johnson L, Galliart M, Brown S, Shelton J, Herndon N, et al. Inferential considerations for low-count RNA-seq transcripts: a case study on the dominant prairie grass Andropogon gerardii. BMC Genomics. 2016;17:140.

51. Kolde R pheatmap: Pretty Heatmaps. R package version 1.0.8. 2015. http://CRAN.R-project.org/package_pheatmap.

52. Zybailov B, Mosley AL, Sardiu ME, Coleman MK, Florens L, Washburn MP. Statistical analysis of membrane proteome expression changes in Saccharomyces cerevisiae. J Proteome Res. 2006;5:2339-47.

53. Ye L, Shao MF, Zhang T, Tong AHY, Lok S. Analysis of the bacterial community in a laboratory-scale nitrification reactor and a wastewater treatment plant by 454 -pyrosequencing. Water Res. 2011;45:4390-8.

54. Mundinger AB, Lawson CE, Jetten MSM, Koch H, Lücker S. Cultivation and transcriptional analysis of a canonical Nitrospira under stable growth conditions. Front Microbiol. 2019;10:1325.

55. Sakoula D, Nowka B, Spieck E, Daims H, Lücker S. The draft genome sequence of "Nitrospira lenta" strain BS10, a nitrite oxidizing bacterium isolated from activated sludge. Stand Genom Sci. 2018;13:32.

56. Chadwick GL, Hemp J, Fischer WW, Orphan VJ. Convergent evolution of unusual complex I homologs with increased proton pumping capacity: energetic and ecological implications. ISME J. 2018;12:2668-80.

57. Cosseau C, Batut J. Genomics of the $c c o N O Q P$-encoded $c b b_{3}$ oxidase complex in bacteria. Arch Microbiol. 2004;181:89-96.

58. Lücker S, Nowka B, Rattei T, Spieck E, Daims H. The genome of Nitrospina gracilis illuminates the metabolism and evolution of the major marine nitrite oxidizer. Front Microbiol. 2013;4:27.

59. Luoto HH, Belogurov GA, Baykov AA, Lahti R, Malinen AM. $\mathrm{Na}^{+}$-translocating membrane pyrophosphatases are widespread in the microbial world and evolutionarily precede $\mathrm{H}^{+}$-translocating pyrophosphatases. J Biol Chem. 2011;286:21633-42. 
60. Luoto HH, Baykov AA, Lahti R, Malinen AM. Membraneintegral pyrophosphatase subfamily capable of translocating both $\mathrm{Na}^{+}$and $\mathrm{H}^{+}$. Proc Natl Acad Sci USA. 2013;110:1255-60.

61. Hausmann B, Pelikan C, Herbold CW, Köstlbacher S, Albertsen M, Eichorst SA, et al. Peatland Acidobacteria with a dissimilatory sulfur metabolism. ISME J. 2018;12:1729-42.

62. Füssel J, Lücker S, Yilmaz P, Nowka B, van Kessel MAHJ, Bourceau P, et al. Adaptability as the key to success for the ubiquitous marine nitrite oxidizer Nitrococcus. Sci Adv. 2017;3:2-10.

63. Ma K, Weiss R, Adams MWW. Characterization of hydrogenase II from the hyperthermophilic archaeon Pyrococcus furiosus and assessment of its role in sulfur reduction. J Bacteriol. 2000; 182:1864-71.

64. Price GD, Woodger FJ, Badger MR, Howitt SM, Tucker L. Identification of a SulP-type bicarbonate transporter in marine cyanobacteria. Proc Natl Acad Sci USA. 2004;101:18228-33.

65. Fukaya F, Promden W, Hibino T, Tanaka Y, Nakamura T, Takabe T. An Mrp-like cluster in the halotolerant cyanobacterium Aphanothece halophytica functions as a $\mathrm{Na}^{+} / \mathrm{H}^{+}$antiporter. Appl Environ Microbiol. 2009;75:6626-9.

66. Chistoserdova L, Crowther GJ, Vorholt JA, Skovran E, Portais JC, Lidstrom ME. Identification of a fourth formate dehydrogenase in Methylobacterium extorquens AM1 and confirmation of the essential role of formate oxidation in methylotrophy. J Bacteriol. 2007;189:9076-81.

67. Lesser MP. Oxidative stress in marine environments: biochemistry and physiological ecology. Annu Rev Physiol. 2006;68:253-78.

68. Heelis PF, Kim ST, Okamura T, Sancar A. The photo-repair of pyrimidine dimers by DNA photolyase and model systems. J Photochem Photobio B. 1993;17:219-28.

69. Roberts M. Organic compatible solutes of halotolerant and halophilic microorganisms. Saline Syst. 2005;1:5.

70. Csonka L. Prokaryotic osmoregulation: genetics and physiology. Annu Rev Microbiol. 1991;45:569-606.

71. Boysen AK, Carlson LT, Durham BP, Groussman RD, Aylward FO, Heal KR, et al. Diel Oscillations of Particulate Metabolites Reflect Synchronized Microbial Activity in the North Pacific Subtropical Gyre. bioRxiv 2020. https://doi.org/10.1101/2020. 05.09.086173.

72. Bayer B, Hansman RL, Bittner MJ, Noriega-Ortega BE, Niggemann J, Dittmar T, et al. Ammonia-oxidizing archaea release a suite of organic compounds potentially fueling prokaryotic heterotrophy in the ocean. Environ Microbiol. 2019;21:4062-75.

73. Sañudo-Wilhelmy SA, Gómez-Consarnau L, Suffridge C, Webb EA. The role of B vitamins in marine biogeochemistry. Ann Rev Mar Sci. 2014;6:339-67.

74. Graham RM, Deery E, Warren MJ. Vitamin $B_{12}$ : Biosynthesis of the Corrin Ring. Tetrapyrroles: Birth, Life and Death. New York, NY: Springer; 2009. pp. 286-99.

75. Shelton AN, Seth EC, Mok KC, Han AW, Jackson SN, Haft DR, et al. Uneven distribution of cobamide biosynthesis and dependence in bacteria predicted by comparative genomics. ISME J. 2019;13:789-804.

76. Mueller AJ, Jung M-Y, Strachan CR, Herbold CW, Kirkegaard RH, Wagner $M$, et al. Genomic and kinetic analysis of novel Nitrospinae enriched by cell sorting. ISME J. 2020. https://doi. org/10.1038/s41396-020-00809-6.

77. Park S-J, Andrei A-Ş, Bulzu P-A, Kavagutti VS, Ghai R, Mosier AC Expanded diversity and metabolic versatility of marine nitrite-oxidizing bacteria revealed by cultivation- and genomicsbased approaches. Appl Environ Microbiol 2020. https://doi.org/ 10.1128/AEM.016667-20.

78. Hawco NJ, McIlvin MM, Bundy RM, Tagliabue A, Goepfert TJ, Moran DM, et al. Minimal cobalt metabolism in the marine cyanobacterium Prochlorococcus. Proc Natl Acad Sci USA. 2020;12. https://doi.org/10.1073/pnas.2001393117.
79. Saito MA, Rocap G, Moffett JW. Production of cobalt binding ligands in a Synechococcus feature at the Costa Rica upwelling dome. Limnol Oceanogr. 2005;50:279-90.

80. Noble AE, Ohnemus DC, Hawco NJ, Lam PJ, Saito MA. Coastal sources, sinks and strong organic complexation of dissolved cobalt within the US North Atlantic GEOTRACES transect GA03. Biogeosciences. 2017;14:2715-39.

81. Füssel J, Lam P, Lavik G, Jensen MM, Holtappels M, Günter M, et al. Nitrite oxidation in the Namibian oxygen minimum zone. ISME J. 2012;6:1200-9.

82. Sun X, Kop LFM, Lau MCY, Frank J, Jayakumar A, Lücker S, et al. Uncultured Nitrospina-like species are major nitrite oxidizing bacteria in oxygen minimum zones. ISME J. 2019;13: 2391-402.

83. D'Hondt S, Inagaki F, Zarikian CA, Abrams LJ, Dubois N, Engelhardt T, et al. Presence of oxygen and aerobic communities from sea floor to basement in deep-sea sediments. Nat Geosci. 2015;8:299-304.

84. Karstensen J, Stramma L, Visbeck M. Oxygen minimum zones in the eastern tropical Atlantic and Pacific oceans. Prog Oceanogr. 2008;77:331-50.

85. Vollmer AC, Bark SJ Twenty-five years of investigating the universal stress protein: function, structure, and applications. advances in applied microbiology, 1st ed. 2018. Elsevier Inc., pp 1-36.

86. Nyström T, Neidhardt FC. Expression and role of the universal stress protein, UspA, of Escherichia coli during growth arrest. Mol Microbiol. 1994;11:537-44.

87. O'Toole R, Smeulders MJ, Blokpoel MC, Kay EJ, Lougheed K, Williams HD. A two-component regulator of universal stress protein expression and adaptation to oxygen starvation in Mycobacterium smegmatis. J Bacteriol. 2003;185:1543-54.

88. Coulthurst S. The Type VI secretion system: a versatile bacterial weapon. Microbiology. 2019;165:503-15.

89. Gallique M, Bouteiller M, Merieau A. The type VI secretion system: a dynamic system for bacterial communication? Front Microbiol. 2017;8:1454.

90. Mellbye BL, Spieck E, Bottomley PJ, Sayavedra-Soto LA. Acyl-homoserine lactone production in nitrifying bacteria of the genera Nitrosospira, Nitrobacter, and Nitrospira identified via a survey of putative quorum-sensing genes. Appl Environ Microbiol. 2017;83:e01540-17.

91. Erb TJ. Carboxylases in natural and synthetic microbial pathways. Appl Environ Microbiol. 2011;77:8466-77.

92. Yamamoto M, Arai H, Ishii M, Igarashi Y. Role of two 2oxoglutarate:ferredoxin oxidoreductases in Hydrogenobacter thermophilus under aerobic and anaerobic conditions. FEMS Microbiol Lett. 2006;263:189-93.

93. Ikeda T, Ochiai T, Morita S, Nishiyama A, Yamada E, Arai H, et al. Anabolic five subunit-type pyruvate:ferredoxin oxidoreductase from Hydrogenobacter thermophilus TK-6. Biochem Biophys Res Commun. 2006;340:76-82.

94. Yun NR, Yamamoto M, Arai H, Ishii M, Igarashi Y. A novel five-subunit-type 2-oxoglutalate:ferredoxin oxidoreductases from Hydrogenobacter thermophilus TK-6. Biochem Biophys Res Commun. 2002;292:280-6.

95. Kletzin A, Adams MWW. Molecular and phylogenetic characterization of pyruvate and 2-ketoisovalerate ferredoxin oxidoreductases from Pyrococcus furiosus and pyruvate ferredoxin oxidoreductase from Thermotoga maritima. J Bacteriol. 1996;178:248-57.

96. Berg IA. Ecological aspects of the distribution of different autotrophic $\mathrm{CO}_{2}$ fixation pathways. Appl Environ Microbiol. 2011;77:1925-36.

97. Pineda E, Encalada R, Rodríguez-Zavala JS, Olivos-García A, Moreno-Sánchez R, Saavedra E. Pyruvate:ferredoxin 
oxidoreductase and bifunctional aldehyde-alcohol dehydrogenase are essential for energy metabolism under oxidative stress in Entamoeba histolytica. FEBS J. 2010;277:3382-95.

98. Preisig O, Zufferey R, Thöny-Meyer L, Appleby CA, Hennecke H. A high-affinity $c b b_{3}$-type cytochrome oxidase terminates the symbiosis-specific respiratory chain of Bradyrhizobium japonicum. J Bacteriol. 1996;178:1532-8.

99. Han H, Hemp J, Pace LA, Ouyang H, Ganesan K, Roh JH, et al. Adaptation of aerobic respiration to low $\mathrm{O}_{2}$ environments. Proc Natl Acad Sci USA. 2011;108:14109-14.

100. Ngugi DK, Blom J, Stepanauskas R, Stingl U. Diversification and niche adaptations of Nitrospina-like bacteria in the polyextreme interfaces of Red Sea brines. ISME J. 2016;10: 1383-99.

101. Shao MF, Zhang T, Fang HHP. Sulfur-driven autotrophic denitrification: diversity, biochemistry, and engineering applications. Appl Microbiol Biotechnol. 2010;88:1027-42.

102. Mulkidjanian AY, Dibrov P, Galperin MY. The past and present of the sodium energetics: May the sodium-motive force be with you. Biochim Biophys Acta. 2008;1777:985-92.

103. Watson SW, Waterbury JB. Characteristics of two marine nitrite oxidizing bacteria, Nitrospina gracilis nov. gen. nov. sp. and Nitrococcus mobilis nov. gen. nov. sp. Arch Mikrobiol. 1971;77:203-30. 